\title{
Accumulated litter and nutrient stock in biomass and in soil in forest formations in the Cerrado
}

\author{
Serapilheira acumulada e estoque de nutrientes na biomassa e no solo em \\ formações florestais no Cerrado
}

Thalles Oliveira Martins ${ }^{1}$ (D), Carlos de Melo e Silva-Neto ${ }^{1,2}$ (D), Karoline Nascimento Siqueira ${ }^{3}$ (D), Hellen Cristina de Sousa Carvalho ${ }^{3}$ (1), Douglas César de Moraes ${ }^{3}$ (D), Pedro Henrique Fernandes Silva ${ }^{3}$ (D), Carolinne de Sousa Fonseca ${ }^{3}$ (D), Fábio Venturoli ${ }^{3}$ (D), Francine Neves Calil ${ }^{3}$ (D)

'Universidade Estadual de Goiás - UEG, Anápolis, GO, Brasil. ${ }^{2}$ Instituto Federal de Goiás - IFG, Cidade de Goiás, GO, Brasil 3Universidade Federal de Goiás - UFG, Goiânia, GO, Brasil.

How to cite: Martins, T. O., Silva-Neto, C. M., Siqueira, K. N., Carvalho, H. C. S., Moraes, D. C., Silva, P. H. F., Fonseca, C. S., Venturoli, F., Calil, F. N. (2021). Accumulated litter and nutrient stock in biomass and soil in forest formations in the cerrado. Scientia Forestalis, 49(129), e3427. https://doi.org/10.18671/scifor.v49n129.18

\begin{abstract}
The physiognomy of the Cerrado can be understood in part with regards the structural aspect of the vegetation and botanical composition. However, little is known about the dynamics of the biomass of the different forest formations in the soil and their respective nutritional contribution. Thus, the objective of this work was to evaluate the accumulated litter and nutrient stock in the biomass and soil in forest formations (Cerradão and semideciduous seasonal forest) in the Cerrado biome. The litter samplings were carried out during the dry period. The accumulated litter biomass was higher in the Cerradão (10.8 Mg.ha-1) than in the semideciduous seasonal Forest $\left(8.3 \mathrm{Mg} \mathrm{ha}^{-1}\right)$. Soil and biomass nutrient contents of $\mathrm{Ca}, \mathrm{Mg}, \mathrm{K}$, and $\mathrm{P}$ were higher in the semideciduous seasonal forest. The carbon content in the Cerradão biomass was higher $\left(460.7 \mathrm{~g}_{\mathrm{kg}} \mathrm{g}^{-1}\right)$ than the semideciduous seasonal forest $\left(453.9 \mathrm{~g} . \mathrm{kg}^{-1}\right)$. Nitrogen was higher in the biomass of the semideciduous seasonal Forest $\left(13.7 \mathrm{~g} . \mathrm{kg}^{-1}\right)$ than in the Cerradão $\left(10.6 \mathrm{~g} . \mathrm{kg}^{-1}\right)$. The principal component analysis (PCA) indicated the formation of two main components, which account for $70.0 \%$ of the variance. The $\mathrm{C} / \mathrm{N}$ ratio was higher in the Cerradão biomass in all components (leaves, branches and bark, and miscellaneous).
\end{abstract}

Keywords: Semideciduous seasonal forest; Cerradão; Soil; Litter; Nutrient cycling.

\section{Resumo}

As fisionomias do Cerrado começam a ser entendidas quanto ao aspecto estrutural da vegetação e composição botânica. Porém pouco ainda é conhecido sobre a dinâmica da biomassa das diferentes formações florestais no solo e seu aporte nutricional. Assim, o objetivo deste trabalho foi avaliar a serapilheira acumulada e o estoque de nutrientes na biomassa e no solo em formações florestais (Cerradão e Floresta estacional semidecidual) no bioma Cerrado. As amostragens da serapilheira foram realizadas no período seco. A biomassa da serapilheira acumulada foi superior no Cerradão $\left(10,8 \mathrm{Mg}\right.$.ha-1 ${ }^{-1}$ em relação a Floresta estacional semidecidual (8,3 Mg.ha-1). Os teores de nutrientes do solo e da biomassa de Ca, Mg, $\mathrm{K}$ e $\mathrm{P}$ foram maiores na Floresta estacional semidecidual. $\mathrm{O}$ teor de carbono na biomassa do Cerradão foi maior (460,7 g.kg-1) em relação à Floresta estacional semidecidual (453,9 g. $\left.\mathrm{kg}^{-1}\right)$. O nitrogênio foi maior na biomassa da Floresta estacional semidecidual $\left(13,7 \mathrm{~g}^{\mathrm{kg}}{ }^{-1}\right)$ em relação ao Cerradão $(10,6$ g.kg-1). A PCA indicou a formação de dois componentes principais, que explicam 70,0\% da variância. A relação $\mathrm{C} / \mathrm{N}$ foi maior na biomassa do Cerradão em todos os compartimentos (Folhas, galhos e miscelânea).

Palavras-chave: Floresta estacional semidecídua; Cerradão; solo; Serapilheira; Ciclagem de nutrientes.

Financial support: Federal Institute of Goiás.

Conflict of interest: nothing to declare.

Correspondig author: carloskoa@gmail.com

Received: 08 July 2019.

Accepted: 20 January 2020.

Editor: Paulo Henrique Müller Silva.

(c) (i) This is an Open Access article distributed under the terms of the Creative Commons Attribution License, which permits unrestricted use, distribution, and reproduction in any medium, provided the original work is properly cited. 


\section{INTRODUCTION}

In most terrestrial ecosystems and tropical regions, litter decomposition is controlled by three main factors: incubation environment, litter quality, and decomposition community composition (Coûteaux et al., 1995). These three factors modulate carbon and nutrient fluxes with different relative contributions in different ecosystems (Liu et al., 2018).

In addition, the ecosystem nutrient cycle can be taken advantage of as litter allows for reuse through the decomposition process, which releases to the soil mineral elements that can be reabsorbed by the roots of the plants (Schumacher et al., 2003; Silva et al., 2007). Therefore, this organic matter is indispensable for the maintenance and the balance of any forest biome (Barbosa et al., 2017).

Among the Cerrado phyto-physiognomies, "Cerradão" is usually associated with interfluvial areas in deep and well drained soils (Miguel et al., 2016), commonly found in latosols with medium to low fertility and also in dystrophic cambisols (Ribeiro \& Walter, 2008). This type of area occupies about $1 \%$ of the extent of the cerrado biome (Marimon-Junior \& Haridasan, 2005), presenting a continuous canopy, tree cover that can reach up to $70 \%$, and an average tree height varying between 8 to 15 meters. This provides luminosity conditions that aid in the formation of shrubs and herbaceous strata at different levels with species of reduced epiphytes (Ribeiro \& Walter, 2008).

The semideciduous seasonal forests occupy approximately $15 \%$ of the Cerrado area (ca. $300,000 \mathrm{~km}^{2}$ ) and are among the most degraded and fragmented phyto-physiognomies of this phyto-geographic domain (Felfili, 2003; Pereira et al., 2011). The mesophytic forests are classified as semi-deciduous (or sub-deciduous); meaning that the percentage of trees in the dry season is less than $50 \%$ of the total, and deciduous when this percentage is above this range (Pereira et al., 2011).

Understanding how the functionality of the relationships between floristic diversity and environmental conditions in these ecosystems is a key instrument for biodiversity conservation and ecological studies (Michaelis et al., 2016). These studies also focus on soil attributes, such as the amount and quality of soil organic matter, that influence the variation of cerrado formations (Cremon, 2009).

In this sense, the objective of the present study is to quantify the accumulated litter in its formation components (leaves, branches and bark, and miscellaneous), the nutrient stock contained in the biomass, and the soil of a Cerradão in relation to a semideciduous seasonal forest. Thus, the research aimed to answer the following question: Is there a nutritional difference of the litter and, consequently, in the soil of the cerradão or semideciduous seasonal forest? The aim tested the hypothesis that the litter quality in the semideciduous seasonal forest presents higher levels of macronutrients and higher litter production because it presents a fertile vegetation in relation to the cerradão.

\section{MATERIALS AND METHODS}

\section{Location of study area}

The fragment studied is a forest preservation area with approximately 335 hectares, 250 hectares of Semideciduous Seasonal Forest (FE's) and 85 hectares of Cerradão (CE). This area falls within in the legal reserve of the Capivara farm, located in the National Research Center of Rice and Beans - CNPAF unit of Embrapa. in the municipality of Santo Antônio de Goiás, GO. The geographical coordinates are latitude $16^{\circ} 30^{\prime} 28.63^{\prime \prime} \mathrm{S}$, and longitude $49^{\circ} 17^{\prime} 10.37^{\prime \prime} \mathrm{W}$ with an altitude of 823 meters above sea level.

The climate, according to Köppen classification, is Aw type, that is, savannah tropical, with rainy summers and dry winters (Alvares et al., 2014). The average annual rainfall is $1498 \mathrm{~mm}$, and the temperature is $23^{\circ} \mathrm{C}$ (Silva et al., 2014). The predominant soil is the Red Latosol, according to the Brazilian Soil Classification System (Santos, 2013). 


\section{Methodologys}

There were five replicates used per plot that were organized on the four corners and at the center, based on the methodology of Lima et al. (2015), over 25 plots $(25 \mathrm{~cm} \times 25 \mathrm{~cm}$ $\left(0.0625 \mathrm{~m}^{2}\right)$ ), within the semideciduous seasonal forest and 15 cerradão plots, totaling 200 samples. Sampling was performed during the dry season between May and August, and the litter layer was collected until the mineral soil was exposed.

In the laboratory, the samples were dried in a circulation oven and renewed air at $65^{\circ} \mathrm{C}$ for approximately 72 hours until reaching constant weight. After the litter was dried, a digital scale $(0.1 \mathrm{~g})$ was used to weigh the material of each individual sample. Then, the material was separated with the aid of tweezers into different fractions (leaves, branches/bark, and miscellaneous) before weighing every fraction again.

From the litter collection data, the total amount of dry matter (litter) deposited under the forest floor was estimated. The percentage of each litter fraction was calculated, and the average of the samples of each area studied was obtained. An estimation per unit area (hectare) was performed by extrapolating the dry mass based on the sample area $\left(0.0625 \mathrm{~m}^{2}\right)$ and the dry mass (g) results obtained were converted into $\mathrm{kg} \cdot \mathrm{ha}^{-1}$ (Calil et al., 2016).

Samples composed of litter were formed (every five parcels a composite sample, totaling eight composite samples) and were ground in Wiley type mill, and then they were passed through mesh sieves of $1.0 \mathrm{~mm}$ ( 20 mesh). The determination of the carbon and nitrogen contents were performed by the Dumas method, classified by dry oxidation and performed with elemental analysis. This method is based on the oxidation of samples at high temperature (approximately $1000^{\circ} \mathrm{C}$ ) (Sato et al., 2014). The other nutrient content determinations followed the methodologies described by Tedesco et al. (1995) phosphorus by spectrophotometry ( $P$ by nitric-perchloric digestion), potassium by flame photometry, and calcium and magnesium by atomic absorption spectrometry (all by nitric-perchloric digestion). (Nitrogen - Sulfuric digestion $\mathrm{H}_{2} \mathrm{SO}_{4}+\mathrm{H}_{2} \mathrm{O}_{2}$ - method Kjeldahl (Büchi, Autokjeldahl K-370).

In order to analyze the soil variables, soil samples were taken from each plot at soil layer depths of $0-20 \mathrm{~cm}$, at the four vertices and center, and being both mixed and homogenized. Soil fertility analyses were performed according to the Embrapa procedure (1999), obtaining pH variables in $\mathrm{H}_{2} \mathrm{O}, \mathrm{P}, \mathrm{K}, \mathrm{Ca}, \mathrm{Mg}, \mathrm{Al}$, potential acidity $(\mathrm{H}+\mathrm{Al}), \mathrm{Cu}, \mathrm{Zn}, \mathrm{Fe}, \mathrm{Mn}$, and organic matter $(\mathrm{OM})$, and then, calculations were performed for the cation exchange capacity at pH 7.0 (T).

The data were tested for normality of error distribution and homogeneity of variance with the aid of the Jarque-Bera test with 10000 permutations and Levene test, respectively. For the data that met the normality and homogeneity of variances, differences between the levels of the analyzed factors were verified through analysis of variance and Tukey test at the level of $5 \%$ of probability.

A principal component analysis (PCA) was carried out to evaluate the amount of litter and nutrient contents in the litter and soil of the semideciduous seasonal forest and the Cerradão with a software Past 2.17 (Hammer et al., 2001). The selection of the number of components used in the interpretation of PCA data is an empirical criterion in the literature. It is common to use the identified components that together accumulate at least $70 \%$ of the total variation of the data, indicated by the eigenvalues of each component (Prado et al., 2016). Therefore, in the present study, we used as many components as needed to accumulate at least $70 \%$ of the total variation.

\section{RESULTS AND DISCUSSION}

\section{Accumulated litter}

The average accumulated litter on the soil of the cerradão was $10.8 \mathrm{Mg} \mathrm{ha}^{-1}$. In Table 1, the biomass components of the litter accumulated on the soil in the area can be observed. From the total litter accumulated on the soil of the cerradão, the leaves were responsible for the largest amount of biomass contained in the litter with 59.3\%, followed by branches/bark with $37.4 \%$ and miscellaneous with $3.1 \%$ 
In a study in the Bacaba Municipal Park, Nova Xavantina-MT, Souza et al. (2011) obtained $77.5 \%$ of leaves, $9.5 \%$ fine branches, and $6.1 \%$ of miscellaneous material, noting that the leaf values were larger than those observed in the cerradão of CNPAF. As compared to a typical

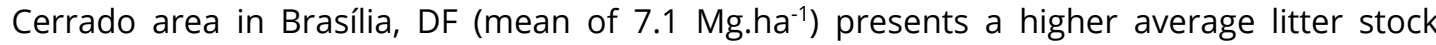
(Ribeiro et al., 2011).

On the soil of the semideciduous seasonal forest, the accumulated litter average was 8.63 Mg.ha ${ }^{-1}$, and it is observed that of this average accumulated biomass production, $42 \%$ is composed of leaves, $51.9 \%$ of branches/bark, and $6.0 \%$ of miscellaneous. The main difference between the litter components of the two phyto-physiognomies is the leaf component. The amount of litter accumulated on the soil in the semideciduous seasonal forest in the Cerrado

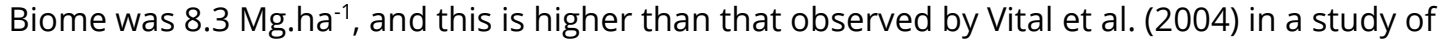
litter accumulated in a seasonal forest semideciduous riparian zone that presented an average

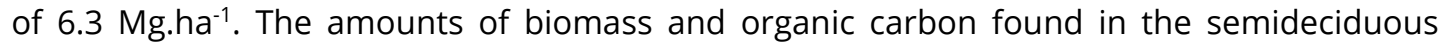
seasonal forest litter were higher than those quantified by Godinho et al. (2014) in a submontane semi-deciduous forest in the state of Espírito Santo. The authors observed 5.5 $\mathrm{Mg} \cdot \mathrm{ha} \mathrm{P}^{-1}$ of biomass and $2.8 \mathrm{Mg} \cdot \mathrm{ha}^{-1}$ of organic carbon.

Table 1. Litter components on the soil of a Cerradão and Semi-deciduous Seasonal Forest area of the National Center for Rice and Bean Research - CNPAF, in Santo Antônio de Goiás - Goiás.

\begin{tabular}{|c|c|c|c|c|}
\hline \multirow{3}{*}{ Components } & Cerradão & \multirow{3}{*}{$\%$} & Floresta Estacional & \multirow{3}{*}{$\%$} \\
\hline & $\mathrm{N}=75$ & & $\mathrm{~N}=125$ & \\
\hline & $\mathbf{x} \pm \mathbf{s}$ & & $\mathbf{x} \pm \mathbf{s}$ & \\
\hline Leaves & $6.4 a( \pm 2.6)$ & 59.3 & $3.6 b( \pm 2.1)$ & 42.0 \\
\hline Branches and bark & $4.0 \mathrm{~b}( \pm 3.5)$ & 37.4 & $4.4 \mathrm{~b}( \pm 3.8)$ & 51.9 \\
\hline Miscellaneous & $0.3 c( \pm 0.5)$ & 3.1 & $0.5 c( \pm 0.9)$ & 6.0 \\
\hline Total & 10.8 & 100 & 8.3 & 100 \\
\hline
\end{tabular}

Mean and standard deviation $(x \pm s)$. Means followed by the same horizontal letter do not differ from one another by the Tukey test at $5 \%$ of error probability.


seasonal forest, the leaf quantity is on average 3.6 Mg.ha-1 ${ }^{-1}$, presenting significant differences between them. Thus, it is probable that the intermediate value of total accumulation of native forest litter $\left(8.3 \mathrm{Mg} \cdot \mathrm{ha}^{-1}\right)$ with a leaf proportion similar to that of the branches (Table 1), is a result of the ecosystem characteristics. The higher species diversity has a predominance of Fabaceae families and a significant number of individuals with DBH higher than $5.0 \mathrm{~cm}$. According to Hedin et al. (2009), higher concentrations of nitrogen and, consequently, higher rates of decomposition are expected for species with potential for $\mathrm{N}$ fixation, such as those of the Fabaceae family.

The branches and miscellaneous components were superior in the semideciduous seasonal forest and did not present significant differences with the same components of Cerradão. Cerradão miscellaneous values were similar to Valadão et al. (2016) in a study of total litter and fractionation in the cerradão in 2011, 2012, and 2013 in the Municipal Park of Bacaba, Nova Xavantina - MT, where values of $0.5 \mathrm{Mg} \cdot \mathrm{ha}^{-1}$ were observed.

\section{Nutrients in the litter deposited on the soil}

The phyto-physiognomies present differences in the macronutrient contents, due to the variability in the concentration and production of plant biomass of the different environments (Table 2). The litter is the main source of $\mathrm{N}_{1} \mathrm{Ca}^{2+}$, and $\mathrm{Mg}^{2+}$ transfer to the soil (Caldeira et al., 2013), as well as phosphorus (P), since more than $90 \%$ of the transfer of this element originates from the same source (Novais et al., 2007). The total nutrient content in the litter reflects the 
concentration of the elements in the plant tissues and the amount of litter produced (Bündchen, 2013).

Table 2. Soil chemical content of the soils $(0-20 \mathrm{~cm})$ and sampled from the seasonal semi-deciduous forest and Cerradão in the CNPAF in Santo Antônio de Goiás - Goiás.

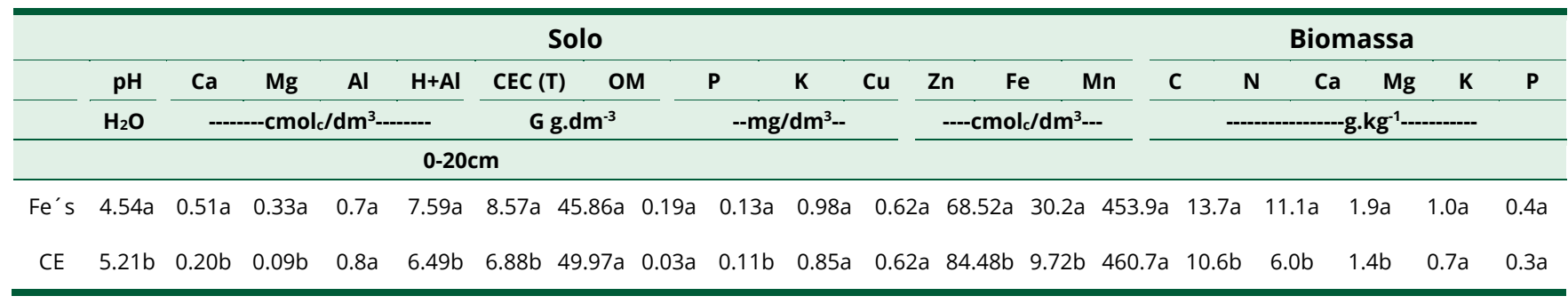

Means followed by the same letter vertically do not differ from each other by the Tukey test at 5\% of error probability.

The mean carbon (C) values of the litter were $453.9{\mathrm{~g} . \mathrm{kg}^{-1}}^{-1}(45.39 \%)$ for the seasonal semideciduous rainforest and 460.7 g. $\mathrm{kg}^{-1}$ (46.07\%) for Cerradão (Table 2). Barbosa et al. (2017) studied three areas, one native forest and two of homogeneous forest plantations, one of Peltogyne nitens Tul., and another one of eucalyptus (E. urophylla S. T. Blake) of six and five years, respectively, located in the southwestern region of Bahia, and found an average organic carbon content of $43 \%, 40 \%$, and $27 \%$.

According to the stages of successional development of forest ecosystems, nitrogen is initially the main limiting factor for plant growth (Davidson et al., 2004). Thus, even with lower litter accumulation observed in the semideciduous seasonal forest in relation to Cerradão, this forest cover may represent a high rate of decomposition. This is due to the higher $\mathrm{N}$ content of the litter components, as evidenced by the significant difference for the averages by the Tukey test at $5 \%$ probability of error.

Two main components were identified from the principal component analysis (PCA), being the order of the total litter quantity and the nutrient content in the litter and soil between the semideciduous seasonal Forest and Cerradão, and together they account for $70.0 \%$ of variance (Figure 1). The first principal component represents $54.0 \%$ of the total variance, and the second component represents $16.0 \%$. These two components divided the plots of the two phyto-physiognomies based on soil fertility and biomass. The semideciduous seasonal forest (FES) plots are associated with higher natural fertility, with higher levels of $\mathrm{Mg}^{2+}, \mathrm{Ca}^{2+}, \mathrm{K}^{+}$, and $\mathrm{P}^{-}$, and consequently a higher sum of bases (SB) and saturation by bases (V\%) in the soil, as a result of nutrients in biomass such as nitrogen, for example. Cerradão (CD) plots are associated with $\mathrm{pH}$ in $\mathrm{H}_{2} \mathrm{O}$, with $\mathrm{Al}^{3+}$, higher amount of organic matter (OM), carbon, and biomass.

The soil of the Semi-deciduous Seasonal Forest presents greater availability of nutrients compared to the Cerradão. This greater contribution in nutrients plays a fundamental role in the distribution and the richness of the species that are found in the Semi-deciduous Seasonal Forest, corroborating that of Martins et al. (2016) in a study on semideciduous seasonal forest and Cerradão in the municipality of Chapadão do Céu, Goiás.

The content of aluminum saturation in all the two phyto-physiognomies and sampled layers was considered very high. This soil acidity decreases the availability of nutrients such as $\mathrm{Ca}^{2+}, \mathrm{Mg}^{2+}$, and $\mathrm{K}^{+}$and increases the solubility of toxic cations $\left(\mathrm{H}^{+}, \mathrm{Al}^{3+}\right)$. The nutritional profile for both communities is not favorable, due to high saturation rates for aluminum, $\mathrm{H}^{+}$and iron oxides, as well as low CEC present in the weathered soil of this forest. However, this soil has its natural characteristics conserved, creating a favorable environment so that most of the charges in its particles are generated by the dissociation of functional clusters present in organic matter (Kerbauy, 2008). 


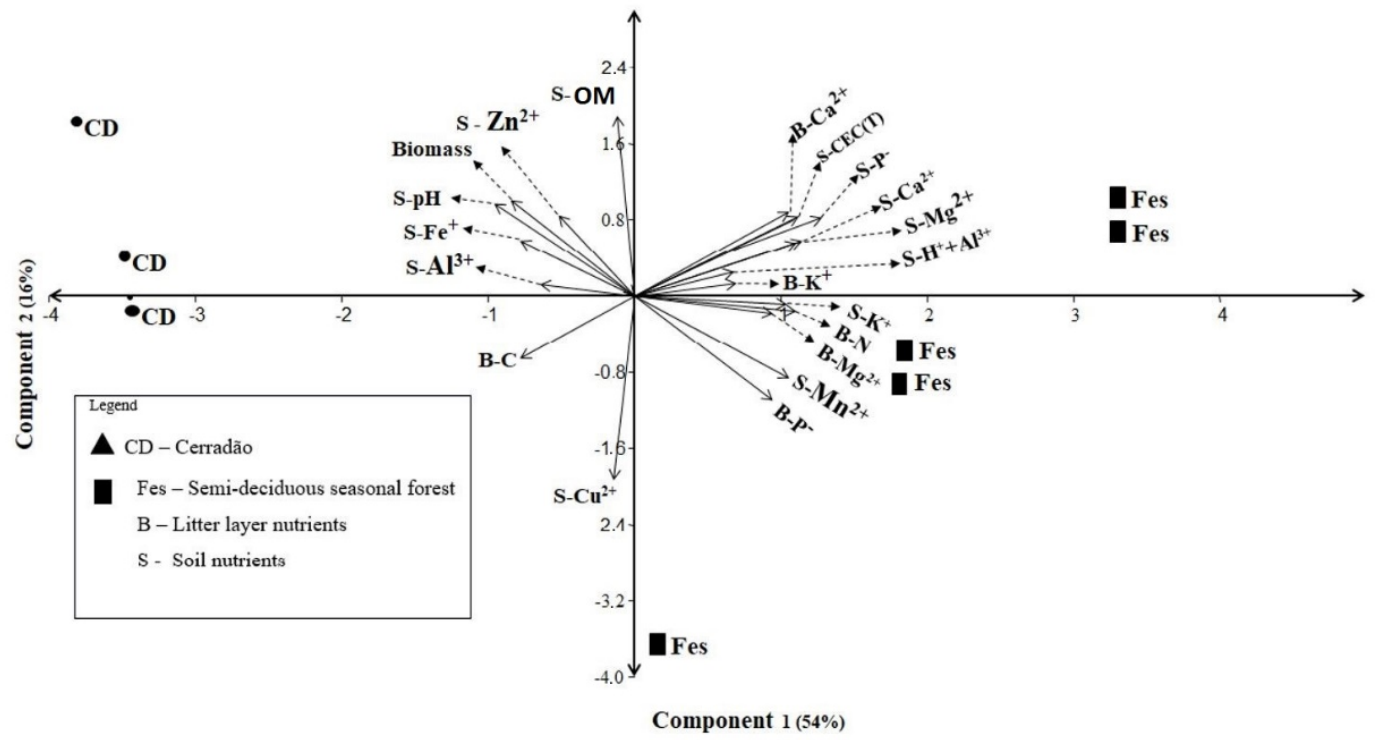

Figure 1. Principal component analysis (PCA) comparing the amount of litter and nutrient contents in litter and soil between the Semi-deciduous Seasonal Forest and Cerradão.

As the soil and climate conditions of the two forest formations are similar, it is probable that the greatest accumulation of deciduous material verified in the settlement of Cerradão is related to the quantity and quality of the residues deposited by the species or to the characteristics of the decomposing population. In this sense, the higher $\mathrm{C} / \mathrm{N}$ ratios found in the litter of this ecosystem (Table 3), in relation to the semideciduous seasonal forest, corroborate this hypothesis because it denotes greater recalcitrance of the material.

Table 3. $\mathrm{C} / \mathrm{N}$ ratio of the litter fractions of the two ecosystems of the National Center for Rice and Bean Research - CNPAF in Santo Antônio de Goiás - Goiás.

\begin{tabular}{cccc}
\hline \multirow{2}{*}{ Ecosystem } & \multicolumn{3}{c}{ C/N RATIO } \\
\cline { 2 - 4 } & Leaves & Braches/bark & Miscellaneous \\
\hline Cerradão & $42.9^{\mathrm{a}}$ & $48.7^{\mathrm{a}}$ & $32.1^{\mathrm{a}}$ \\
Floresta Estacional Semidecidua & $28.8^{\mathrm{b}}$ & $41.4^{\mathrm{b}}$ & $31.2^{\mathrm{a}}$ \\
\hline
\end{tabular}

Means followed by the same letter vertically do not differ from each other by the Tukey test at $5 \%$ of error probability.

It can be observed that several factors condition this return of nutrients, among which are the diversity of species that is high in the study, the chemical composition of the litter, the performance of edaphic organisms, and the chemical properties of the soil (Barbosa et al., 2017). Within the various chemical aspects of the litter, it is clear that the decomposition of the foliage and the availability of its nutrients in the soil contribute to the improvement of its characteristics, helping to maintain the physiognomy that presents specific adaptations, such as high acidity and a lack of some nutrients. These conditions further reinforce the role of the litter as a nutritional source and maintain the quality of the soil and vegetation, since part of the nutrients necessary for the survival of the vegetation comes totally from that foliage.

The soil, relief, and hydrographic aspects contribute to the formation and phytophysiognomy interaction in a way for organic material deposition, and consequently results in nutritional deposition to maintain this vegetation, even with species specific relationships. This total balance tends to hold, but is it possible they move and change to another formation. In this sense, further studies, in well preserved semideciduous seasonal Forest and Cerradões, will be necessary in different regions to confirm the occurrence of the indicator species, as well as the determinant pedological characteristics of the abundant distribution of these factors in the sampled area. 


\section{CONCLUSIONS}

The investigation showed that the two contiguous forest formations differ in relation to the soil fertility and litter, forming different groups that consist of vegetation in two physiognomies: Cerradão and Semi-deciduous Seasonal Forest. The two forest formations of the Cerrado, which are established in the same vegetation unit with common characteristics, present variations in their composition, being related to the differentiation in the edaphic variables.

\section{ACKNOWLEDGEMENTS}

The second author, Carlos de Melo e Silva-Neto technologist in agroecology, thanks the support to the Federal Institute of Goiás the realization of the research.

\section{REFERENCES}

Alvares, C. A., Stape, J. L., Sentelhas, P. C., Gonçalves, J. L. M., Sparovek, G. (2014). Koppen's climate classification map for Brazil. Meteorologische Zeitschrift, 22(711-728), 17-626. http://dx.doi.org/10.1127/0941-2948/2013/0507

Barbosa, V., Barreto-Garcia, P., Gama-Rodrigues, E., \& Paula, A. (2017). Biomassa, carbono e nitrogênio na serapilheira acumulada de florestas plantadas e nativa. Revista Floresta e Ambiente, 24(0), e20150243. http://dx.doi.org/10.1590/2179-8087.024315.

Bündchen, M. (2013). Status nutricional e eficiência no uso de nutrientes em espécies arbóreas da floresta subtropical no sul do Brasil. Scientia Forestalis, 41(2), 227-236.

Caldeira, M. V. W., Delarmelina, W. M., Faria, J. C. T., \& Juvanhol, R. S. (2013). Substratos alternativos na produção de mudas de Chamaecrista desvauxii. Revista Árvore, 37(1), 31-39. http://dx.doi.org/10.1590/S0100-67622013000100004.

Calil, F. N., Lima, N. L., Silva, R. T., Moraes, M. D. A., Barbosa, P. V. G., Lima, P. A. F., Brandão, D. C., SilvaNeto, C. M., Carvalho, H. C. S., \& Nascimento, A. R. (2016). Biomass and nutrition stock of grassland and accumulated litter in a silvopastoral system with Cerrado species. African Journal of Agricultural Research, 11(38), 3701-3709. http://dx.doi.org/10.5897/AJAR2016.11369.

Coûteaux, M. M., Bottner, P., \& Berg, B. (1995). Litter decomposition, climate and litter quality. Trends in Ecology \& Evolution, 10(2), 63-66. PMid:21236954. http://dx.doi.org/10.1016/S0169-5347(00)88978-8.

Cremon, C. (2009). Análise micromorfométrica de agregados de um Latossolo Vermelho distroférrico sob diferentes sistemas de manejo. Acta Scientiarum, 31(1), 139-146. http://dx.doi.org/10.4025/actasciagron.v31i1.6640.

Davidson, E. A., Carvalho, J. R., Vieira, I. C. G., Figueiredo, P. M., Ishida, F. Y., Santos, M. T. P., Guerrero, J. B., Kalif, K., \& Sabá, R. T. (2004). Nitrogen and phosphorus limitation of biomass growth in a tropical secondary forest. Ecological Applications, 14(sp4), 154-163. http://dx.doi.org/10.1890/01-6006.

Felfili, J. M. (2003). Fragmentos de florestas estacionais do Brasil Central: diagnóstico e proposta de corredores ecológicos. In: Costa, R. B. (Org.), Fragmentação florestal e alternativas de desenvolvimento rural na Região Centro-Oeste (pp. 195-263). Campo Grande: Universidade Católica Dom Bosco.

Godinho, T. O., Caldeira, M. V. W., Rocha, J. H. T., Caliman, J. P., \& Trazzi, P. A. (2014). Quantificação de biomassa e nutrientes na serapilheira acumulada em trecho de floresta estacional semidecidual submontana, ES. Cerne, 20(1), 11-20. http://dx.doi.org/10.1590/S0104-77602014000100002.

Hammer, Ø., Harper, D. A. T., \& Ryan, P. D. (2001). PAST: Paleontological statistics software package for education and data analysis. Palaeontologia Electronica, 4(1): 9.

Hedin, L. O., Brookshire, E. J., Menge, D. N., \& Barron, A. R. (2009). The nitrogen paradox in tropical forest ecosystems. Annual Review of Ecology Evolution and Systematics, 40(1), 613-635. http://dx.doi.org/10.1146/annurev.ecolsys.37.091305.110246.

Kerbauy, G. B. (2008). Fisiologia vegetal. (2. Ed.). Rio de Janeiro: Guanabara Koogan.

Lima, N. L., Silva-Neto, C. M., Calil, F. N., Souza, K. R., \& Moraes, D. C. (2015). Acúmulo de serapilheira em quatro tipos de vegetação no estado de Goiás. Enciclopédia Biosfera, 11(22), 39-46. http://dx.doi.org/10.18677/Enciclopedia_Biosfera_2015_068.

Liu, G., Wang, L., Jiang, L., Pan, X., Huang, Z., Dong, M., \& Cornelissen, J. (2018). Specific leaf area predicts dryland litter decomposition via two mechanisms. Journal of Ecology, 106(1), 218-229. http://dx.doi.org/10.1111/1365-2745.12868.

Marimon-Junior, B. H., \& Haridasan, M. (2005). Comparação da vegetação arbórea e características edáficas de um cerradão e um cerrado sensu stricto em áreas adjacentes sobre solo distrófico no 
leste de Mato Grosso, Brasil. Acta Botanica Brasílica, 19(4), 913-926. http://dx.doi.org/10.1590/S010233062005000400026.

Martins, T. O., Araújo, F. D., Siqueira, K. N., Ribeiro, A. C. C., \& Silva-Neto, C. M. (2016). Cerrado forests: Seasonal Forest and Cerradão. Agrarian Academy, 3(06), 1-14. http://dx.doi.org/10.18677/Agrarian_Academy_2016b21.

Michaelis, J., Pannek, A., \& Diekmann, M. (2016). Soil pH limits of forest vascular plants determine range size and threat level. Journal of Vegetation Science, 27(2), 315-322. http://dx.doi.org/10.1111/jvs.12380.

Miguel, E. D., Rezende, A. V., Leal, F. A., Pereira, R. S., \& de Melo, R. R. (2016). Floristic-structural characterization and successional group of tree species in the Cerrado biome of Tocantins state, Brazil. Revista Caatinga, 29(2), 393-404. http://dx.doi.org/10.1590/1983-21252016v29n216rc.

Novais, R. F., Smyth, T. J., \& Nunes, F. N. (2007). Fósforo. In R. F. Novais, V. V. H. Alvarez, N. F. Barros, R. L. F. Fontes, R. B. Cantarutti, \&J. C. L. Neves. Fertilidade do solo (pp. 471-550). Viçosa: Sociedade Brasileira de Ciência do Solo - SBCS.

Pereira, B. A. S., Venturoli, F., \& Carvalho, F. A. (2011). Florestas estacionais no cerrado: uma visão geral. Pesquisa Agropecuária Tropical, 41(3), 446-445. http://dx.doi.org/10.5216/pat.v41i3.12666.

Prado, B. Q. M., Fernandes, H. R., Araújo, T. G., Laia, G. A., \& Biase, N. G. (2016). Avaliação de variáveis climatológicas da cidade de Uberlândia (MG) por meio da análise de componentes principais. Engenharia Sanitaria e Ambiental, 21(2), 407-413. http://dx.doi.org/10.1590/s1413-41522016147040.

Ribeiro, J. F., \& Walter, B. M. T. (2018). As principais fitofisionomias do Bioma Cerrado. In: S. M. Sano, S. P. Almeida, J. F. Ribeiro (Eds.), Cerrado: Ecologia e Flora (pp. 151-212). Brasília: Embrapa Cerrados.

Ribeiro, S. C., Fehrmann, L., Soares, C. P. B., Jacovine, L. A. G., Kleinn, C., \& Gaspar, R. O. (2011). Above and belowground biomass in a Brazilian Cerrado. Forest Ecology and Management, 262(3), 491-499. http://dx.doi.org/10.1016/j.foreco.2011.04.017.

Santos, H. G. (2013). Sistema brasileiro de classificação de solos (3. ed.). Brasília: Embrapa.

Sato, J. H., Figueiredo, C. C. D., Marchão, R. L., Madari, B. E., Benedito, L. E. C., Busato, J. G., \& Souza, D. M. D. (2014). Methods of soil organic carbon determination in Brazilian savannah soils. Scientia Agrícola, 71(4), 302-308. http://dx.doi.org/10.1590/0103-9016-2013-0306.

Schumacher, M. V., Brun, E. J., Rodrigues, L. M., \& Santos, E. M. (2003). Retorno de nutrientes via deposição de serapilheira em um povoamento de acácia-negra (Acacia mearnsii De Wild.) no estado do Rio Grande do Sul. Revista Árvore, 27(6), 791-798. http://dx.doi.org/10.1590/S010067622003000600005.

Silva, C. J., Sanches, L., Bleich, M. E., Lobo, F. A., \& Nogueira, J. S. (2007). Produção de serrapilheira no Cerrado e Floresta de Transição Amazônia-Cerrado do Centro-Oeste Brasileiro. Acta Amazonica, 37(4), 543-548. http://dx.doi.org/10.1590/S0044-59672007000400009.

Silva, S. C., Heinemann, A. B., Paz, R. L. F., \& Amorim, A. O. (2014). Informações metereológicas para pesquisa e planejamento agrícola, referentes ao Município de Santo Antônio de Goiás, Goiás. Santo Antônio de Goiás: Embrapa Arroz e Feijão.

Souza, M. G. R., Forsthofer, M., Abreu, M. F., Marimon-Junior, B. H., \& Marimon, B. S. (2011). Comparação da produção de serapilheira entre um Cerrado Sentido Restrito e um Cerradão no Parque Municipal de Bacaba, Nova Xavantina MT. In X Congresso Nacional de Ecologia do Brasil. Nova Xavantina: Congresso de Iniciação Científica.

Tedesco, M. J., Gianello, C., Bissani, C. A., Bohnen, H., \& Volkweiss, S. J. (1995). Análise de solo, plantas e outros materiais (2. ed., 174 p.). Porto Alegre: Departamento de Solos da Universidade Federal do Rio Grande do Sul.

Valadão, M. B. X., Marimon-Junior, B. H., Oliveira, B., Lúcio, N. W., Souza, M. G. R., \& Marinon, B. S. (2016). Biomass hyperdynamics as a key modulator of forest self-maintenance in a dystrophic soil in the Amazonia-Cerrado transition. Scientia Forestalis, 44(110), 475-485. http://dx.doi.org/10.18671/scifor.v44n110.20.

Vital, A. R. T., Guerrini, I. A., Franken, W. K., \& Fonseca, R. C. B. (2004). Produção de serapilheira e ciclagem de nutrientes de uma floresta Estacional Semidecidual em Zona Ripária. Revista Árvore, 28(6), 793-800. http://dx.doi.org/10.1590/S0100-67622004000600004.

Authors' contributions: TOM, CMSN, FV and FNC: conceptualization; CMSN: funding acquisition; TOM, CMSN, FV and FNC: supervision, writing; TOM, CMSN, KSN, HCSC, DCM, PHFS and CSF: conceptualization, data curation, formal analysis, methodology; TOM, CMSN, FV and FNC: writing, data curation, formal analysis. 